\title{
Mobbing in the Practice of Polish ENTERPRISES - RECOGNIZABILITY OF THE PHENOMENON
}

\author{
MOBbING W PRAKTYCE POLSKICH \\ PRZEDSIĘBIORSTW - ROZPOZNAWALNOŚĆ ZJAWISKA
}

\begin{abstract}
Systematic, permanent, time-staggered hostile behavior towards an employee are just some of the features of the phenomenon known as mobbing. Such behaviors lead to mental and often physical destruction. We meet with them every day because it has been accompanied by hostility since the beginning of its existence, as an emotion, and the need to acquire and overcome. The motives of applying such behaviors depend not only on the internal characteristics of the human being that enable him to meet his needs. In a professional environment, it is the lack of appropriate rules of mutual coexistence, consent to such behavior by concealing their occurrence as well as deliberate actions.

The article presents the phenomenon of mobbing in the practice of Polish enterprises. It indicates what is mobbing and what behaviors are legally recognized as mobbing. It presents the size of this phenomenon in Poland, its causes as well as the effects of using mobbing for an employee and an entrepreneur. In this article, the author is based on the literature available in this area, compares the research conducted by CBOS in 2002 and 2014, as well as the research by HR Sedlak \& Sedlak, from 2015, and tries to complement this multidimensional problem with its perception by the serial employees.
\end{abstract}




\section{STRESZCZENIE}

Systematyczne, stałe, rozłożone w czasie wrogie zachowania w stosunku do pracownika to tylko niektóre wybrane cechy zjawiska zwanego mobbingiem. Takie zachowania prowadzą do psychicznego, a często też fizycznego wyniszczenia. Spotykamy się z nimi niemal codziennie, ponieważ towarzyszą człowiekowi od początku jego istnienia - u ich podstaw leży wrogość, jako emocja oraz potrzeba zdobywania i pokonywania. Motywy stosowania takich zachowań zależą nie tylko od cech wewnętrznych człowieka, umożliwiających mu zaspokojenie jego potrzeb. W środowisku zawodowym jest to brak odpowiednich zasad wzajemnego współżycia, przyzwolenie na takie zachowania poprzez przemilczanie ich występowania, a także celowe działania.

Artykuł przedstawia zjawisko mobbingu w praktyce polskich przedsiębiorstw. Wskazuje, co jest mobbingiem i jakie zachowania uznawane są przez prawo za mobbing. Przedstawia rozmiar tego zjawiska w Polsce, jego przyczyny, a także skutki stosowania mobbingu dla pracownika i przedsiębiorcy. W artykule Autorka opiera się na dostępnej w tym obszarze literaturze, porównuje badania przeprowadzone przez Centrum Badania Opinii Społecznej (dalej: CBOS) w 2002 i 2014 r., a także badania firmy doradczej HR Sedlak \& Sedlak z 2015 r. oraz podejmuje próbę uzupełnienia tego wielowymiarowego zagadnienia o postrzeganie go przez szeregowych pracowników.

KEYWORDS: mobbing, features of mobbing, research CBOS 2002 and 2014 - „Harassment at the workplace”

SŁOWA KLUCZOWE: mobbing, cechy mobbingu, badania CBOS-u z lat 2002 i 2014 r. „Szykany w miejscu pracy”

\section{ChARAKTERYSTYKA MOBBINGU}

Nazwa „mobbing” pochodzi od angielskiego słowa mob, oznaczającego tłok, bandę, motłoch, napastowanie, zbiorowisko, obleganie lub rzucanie się tłumu na kogoś (Szkatuła, 2010, s. 326). Jako pierwszy wprowadził to pojęcie etnolog Konrad Lorenz, określając nim zachowania dzikich zwierząt, polegające na atakowaniu ofiary oraz przeganianiu intruza (Rybak, 2008, s. 303). Następnie lekarz Peter Paul Heinemann w latach 60. XX w. nazwał mobbingiem agresję i prześladowania wśród uczniów (Szczepanik, 2014, s. 111), chociaż w stosunku do przemocy szkolnej o wiele częściej stosowany jest termin bullying, pochodzący od słowa bully, oznaczającego brutalne obchodzenie się, tyranizowanie, terroryzowanie, zmuszanie siłą. Ze względu na złożoność zjawiska, nie istnieje jednobrzmiąca definicja mobbingu. 
Zagadnieniem mobbingu zajmował się znany szwedzki psycholog i psychiatra Heinz Leymann, definiując mobbing jako

terror psychiczny w miejscu pracy, który angażuje wrogie nastawienie i nieetyczne komunikowanie się (stosowanie w codziennych kontaktach $w$ ramach stosunku pracy obelg, wyzwisk, pomówień, oszczerstw, krzyku itd.) systematycznie podtrzymywane przez jedną, bądź klika osób w stosunku do innej, co w konsekwencji spycha ofiarę do pozycji uniemożliwiającej jej obronę. Działania te zdarzają się często, (co najmniej raz w tygodniu) i trwają przez dłuższy okres czasu (co najmniej pół roku). Z uwagi na czas trwania i częstość, maltretowanie to skutkuje zaburzeniami w sferze psychiki, zdrowia fizycznego i funkcjonowania społecznego ofiary (Leyman, 1996).

Kaj Björkvist, profesor Uniwersytetu Åbo Akademi w Turku w Finlandii, mobbingiem określił „powtarzające się działania, mające na celu wyrządzenie psychicznego (ale czasami również fizycznego) bólu, skierowane wobec jednej osoby bądź grupy osób, które z jakiegoś powodu nie są zdolne do obrony przed nimi” (Łaszkiewicz, 2014, s. 6; Merecz, 2005, s. 7).

Francuska psycholog i psychiatra Marie-France Hirigoyen opisała mobbing jako molestowanie moralne i określiła je jako

niewłaściwe postępowanie (gest, słowo, zachowanie, postawa), które przez swoją powtarzalność czy systematyczność narusza godność lub integralność psychiczną bądź fizyczną osoby, narażając ją na utratę zatrudnienia lub pogarszając atmosferę w pracy (...) Molestowanie moralne to przemoc w małych dawkach, która jest jednak bardzo destrukcyjna. Każdy atak wzięty z osobna jest naprawdę czymś poważnym, o agresji stanowi skumulowany efekt częstych i powtarzalnych mikrourazów (Bechowska-Gebhardt, 2004, s. 11).

Dieter Zapf, niemiecki psycholog, profesor psychologii pracy na Uniwersytecie Johanna Wolfganga Goethego we Frankfurcie nad Menem, zdefiniował mobbing jako

ekstremalnie stresującą sytuację w pracy będącą konsekwencją działań podejmowanych raczej przez grupę osób niż jednostkę w stosunku do określonej osoby (...) Zjawisko o charakterze społecznym, które prowadzi do eskalacji konfliktu, a wraz z jego intensyfikacją do powiększającej się nierównowagi sił (Łaszkiewicz, 2014, s. 6). 
I wreszcie badacze polscy, pracownicy naukowi Politechniki Wrocławskiej, członkowie stowarzyszenia antymobbingowego, Agata Bechowska-Gebhardt i Tadeusz Stalewski, określili zjawisko mobbingu jako

nieetyczne i irracjonalne, z punktu widzenia celów organizacji, działanie, polegające na długotrwałym, powtarzającym się i bezpodstawnym dręczeniu pracownika przez przełożonych i współpracowników; jest to poddanie ofiary przemocy ekonomicznej, psychicznej i społecznej w celu zastraszenia, upokorzenia i ograniczenia jej zdolności obrony; jest to zjawisko odczuwane subiektywnie, ale dające się intersubiektywnie potwierdzić; jest to wielofazowy proces, w którym mobber stosuje metody manipulacji od najbardziej subtelnych i niezauważalnych przez ofiarę po najbardziej drastyczne, powodujące u ofiary izolację społeczną, jej autodeprecjację, poczucie krzywdy, bezsilności i odrzucenia przez współpracowników, a w konsekwencji silny stres i choroby somatyczne i psychiczne (Bechowska-Gebhardt, 2014, s. 16).

Analiza przedstawionych wyżej definicji skłania do uznania mobbingu za „zbiór działań mających na celu zadręczenie psychiczne, poprzez wrogie postępowanie wobec jednego pracownika lub grupy, co wpływa na życie osobiste, zawodowe i zdrowie ofiary" (Merecz i in., 2005, s. 11). Charakterystyczne dla mobbingu działania wymagają spełnienia trzech kryteriów, jakimi są: określony czas trwania, powtarzalność i negatywne intencje towarzyszące sprawcy.

\section{PraWNe UREguloWANIA - CHRONOLOGIA WYDARZEŃ}

Nękanie i przemoc stanowią atak nie tylko na godność człowieka, ale też na prawo do równego i niedyskryminacyjnego traktowania oraz zdrowie danej osoby. Odpowiednie ustawodawstwo zwiększa skuteczność polityki na rzecz przeciwdziałania przemocy i nękaniu.

Kwestie mobbingu zostały po raz pierwszy uregulowane w Szwecji w 1977 r., kiedy to do ustawy o środowisku pracy wprowadzono zapis określający prawo pracownika do ochrony zdrowia fizycznego i psychicznego. Ustawa ta stała się podstawą do wydania przez Narodową Radę Bezpieczeństwa i Zdrowia Zawodowego rozporządzenia w sprawie przeciwdziałania zjawisku dręczenia w miejscu pracy. Weszło ono w życie 31 marca $1994 \mathrm{r}$. Ustawodawcy bardzo ściśle zdefiniowali pojęcie dręczenia w miejscu pracy. 
Obejmuje ono m.in. molestowanie seksualne, przemoc psychiczną oraz inne negatywne długotrwałe działania, które są wymierzone przeciw poszczególnym pracownikom (Chakowski, 2005, s. 17-19).

We Francji problem mobbingu został uregulowany w 2002 r. Wtedy parlament francuski przyjął ustawę o modernizacji socjalnej. Włączono do niej przepisy określające działania antymobbingowe. Jednocześnie znowelizowano kodeks pracy, kodeks karny oraz ustawę o prawach i obowiązkach pracowników służby cywilnej (Chakowski, 2005, s. 17-19; Merecz, 2005, s. 27). W Belgii z kolei parlament w 2002 r. przyjął ustawę, która wprowadziła przepisy dotyczące przeciwdziałania molestowaniu moralnemu i seksualnemu oraz przemocy. Jednocześnie została znowelizowana ustawa dotycząca ochrony pracowników w miejscu pracy oraz przepisy kodeksu karnego w kwestii dotyczącej ochrony przed przemocą (Chakowski, 2005, s. 30-34; Merecz 2005, s. 27). W Hiszpanii w odniesieniu do zjawiska mobbingu stosowane są przepisy dekretu królewskiego o statusie pracowników, szczególnie artykuł mówiący o poszanowaniu prywatności i godności pracowników. Ponadto hiszpańskie sądy odnośnie do tego tematu stworzyły dość jasną linię orzeczniczą (Chakowski, 2005, s. 37-39).

W Niemczech nie istnieją regulacje prawne dotyczące samego mobbingu. Pracownika w tym kraju chronią zapisy Kodeksu cywilnego. Szczególnie $\$ 823$ - „kto umyślnie lub nieumyślnie, wbrew prawu, narusza życie, ciało, zdrowie, wolność, własność lub inne prawo drugiej, osoby jest zobowiązany do naprawienia z tego tytułu szkody”. Także tamtejszy kodeks karny w $\$ 223$ przewiduje karę za fizyczne znęcanie się nad drugą osobą lub spowodowanie uszczerbku na jej zdrowiu. Te zapisy stosuje się do drastycznych form mobbingu. Częściej prawo karne Niemiec stosuje $\$ 185$, mówiący o zniesławieniu i znieważeniu przy użyciu rękoczynów (Chakowski, 2005, s. 39-42; Szewczyk, 2012).

W 2001 r. problem został dostrzeżony w krajach UE przez wielu ustawodawców narodowych. Uznali oni potrzebę uregulowania go na poziomie państw członkowskich. To spowodowało przyjęcie przez Parlament Europejski rezolucji w sprawie nękania w miejscu pracy, która wzywa państwa członkowskie do przeciwdziałania mobbingowi i molestowaniu seksualnemu oraz standaryzacji definicji mobbingu (Chakowski, 2005, s. 52-55; Bilski 2006, s. 26). 
„Od 2002 r. Komisja Europejska rozpoczęła prace nad projektem prawa europejskiego, które wyczerpująco regulowałoby kwestię zachowań uznanych za mobbing w przedsiębiorstwach państw członkowskich” (Kępniak, 2006).

W Polsce po raz pierwszy termin „mobbing” został użyty na początku lat 90., gdy zaczęto tłumaczyć obcojęzyczne artykuły dotyczące tej patologii (Bechowska-Gebhardt, 2004, s. 35-36; Ostrowska, 2013, s. 416) i jako czwarty kraj europejski Polska wprowadziła regulacje prawne mające na celu przeciwdziałanie mobbingowi (Bilski, 2006, s. 22). Ustawą nowelizującą Kodeks pracy $^{1} \mathrm{z}$ dnia 14 listopada 2003 r. wprowadzono art. 94 ${ }^{3}$, który reguluje problem szykanowania w miejscu pracy poprzez zdefiniowanie, czym jest mobbing i nałożenie na pracodawcę obowiązku przeciwdziałania temu zjawisku. Wypracowano uniwersalną definicję mobbingu i sposobu postępowania w przypadku jego zaistnienia.

Definicja mobbingu w Kodeksie pracy brzmi:

Mobbing oznacza działania lub zachowania dotyczące pracownika lub skierowane przeciwko pracownikowi, polegające na uporczywym i długotrwałym nękaniu lub zastraszaniu pracownika, wywołujące u niego zaniżoną ocenę przydatności zawodowej, powodujące lub mające na celu poniżenie lub ośmieszenie pracownika, izolowanie go lub wyeliminowanie z zespołu współpracowników² .

Zakwalifikowanie działań dotyczących pracownika jako mobbing wiąże się ze spełnieniem kilku przesłanek. A mianowicie działania lub zaniechania: 1. Skierowane są bezpośrednio lub pośrednio przeciwko konkretnemu pracownikowi.

2. Związane są z nękaniem, prześladowaniem, szykanowaniem lub zastraszaniem (grożeniem).

3. Charakteryzuje je uporczywość, długotrwałość i systematyczna powtarzalność. Przyjmuje się, że aby dane zachowania można było określić jako naganne, powinny występować przynajmniej raz w tygodniu, a czas ich trwania przekraczać sześć miesięcy (Leyman, 1996). Od stycznia 2004 r. wykładnią przepisów o mobbingu stają się sądy, ponieważ zapadają pierwsze wyroki i pojawiają się różne okoliczności zjawiska, a w związku z tym, także różne stanowiska odnoszące się do długości trwania mobbingu³.

4. Wpływają na obniżenie samooceny przydatności zawodowej pracownika.

5. Poniżają albo ośmieszają pracownika, izolują go lub eliminują z zespołu współpracowników. 
W Polsce kolejne nowe przepisy weszły w życie wraz z dniem uzyskania członkostwa w Unii Europejskiej. Ochronę przed patologiami oraz prawa w miejscu pracy określa także Konstytucja RP w Rozdziale II pt. ,,Wolności, prawa i obowiązki człowieka i obywatela” oraz Kodeks karny, który jasno formułuje sankcje grożące osobie, która swoim działaniem spowodowała u innej osoby uszczerbek na zdrowiu, chorobę psychiczną oraz trwałą niezdolność do pracy. Warto też wspomnieć, że w Polsce od 2002 r. działa Ogólnopolskie Stowarzyszenie Antymobbingowe (OSA), którego oddziały znajdują się w miastach wojewódzkich i powiatowych. Działalność stowarzyszenia obejmuje szeroko rozumianą pomoc prawną, wsparcie psychologiczne oraz udzielanie informacji (Szczepanik, 2014).

\section{CECHY MOBbingu}

Zjawisko mobbingu obejmuje wiele różnorodnych zachowań. O tym, czy dane działanie skierowane przeciwko pracownikowi miało cechy mobbingu, w przypadku procesu każdorazowo decyduje sąd pracy (Chakowski, 2005, s. 65; Śmierciak, 2013, s. 16).

Heinz Leyman opisał 45 działań mobbingowych, stopniując i w zależności od uciążliwości grupując je w 5 poziomów (Ostrowska, 2013, s. 417; op. cit., s. 12-13). Pierwszy poziom to działania związane z procesem porozumiewania się. Są to: ograniczanie możliwości wypowiadania się, notoryczne przerywanie wypowiedzi, gwałtowna negatywna reakcja na uwagi, ciągła krytyka pracy i życia prywatnego, pogróżki ustne albo pisemne, gesty i spojrzenia, mające na celu osaczyć i upokorzyć ofiarę oraz aluzje, bez jasnego komunikowania się wprost (Bilski, 2006, s. 11; Merecz i in., 2005, s. 9; Szczepanik, 2014, s. 113; Delikowska, 2009, s. 11). Działania i zachowania przypisane do drugiego poziomu charakteryzują się tym, że są wymierzone w relacje społeczne. Zalicza się do nich: uniemożliwianie komunikowania się w obrębie zespołu (co prowadzi do eliminacji osoby prześladowanej z grupy pracowników), zachowania mające na celu unikanie rozmów z ofiarą, celowe odbieranie możliwości odezwania się, całkowite ignorowanie obecności ofiary, zabranianie współpracownikom rozmów z nią oraz zmiana stanowiska pracy na takie, które oddalone będzie od kolegów i koleżanek (Bilski, 2006, s. 11-12; 
Merecz i in., 2005, s. 9-10; Szczepanik 2014, s. 113; Delikowska, 2009, s. 11). Następny, trzeci poziom, to działania, których celem jest nadszarpnięcie lub ostateczne zniszczenie reputacji ofiary, rozpuszczanie plotek, wyśmiewanie, atakowanie przekonań i kompetencji ofiary oraz wmawianie jej choroby psychicznej. W ramach tych zachowań mieszczą się również nieprzyzwoite propozycje z podtekstem seksualnym. Ta grupa zachowań obejmuje też niszczenie dobrego imienia poprzez używanie przezwisk i obelg w stosunku do ofiary (Bilski, 2006, s. 12; Merecz i in., 2005, s. 10; Szczepanik, 2014, s. 113; Delikowska, 2009, s. 11). Czwarty poziom nękania to działania, których celem jest przede wszystkim podważenie pozycji zawodowej ofiary. Mobber zmusza ofiarę do wykonywania prac bezsensownych, poniżej lub znacznie powyżej kwalifikacji albo nie zleca jej żadnych zadań, przez co wyraźnie daje do zrozumienia, że jest w organizacji zbędna. Często pojawia się też zmuszanie do wykonywania ciężkiej pracy bez wynagrodzenia (Bilski, 2006, s. 13; Merecz i in., 2005, s. 10; Szczepanik, 2014, s. 114; Delikowska, 2009, s. 12). Do piątego poziomu Heinz Leyman zaliczył najbardziej drastyczne działania, które stanowią zagrożenie dla bezpieczeństwa i zdrowia ofiary, czyli np. zmuszanie do prac, które zagrażają zdrowiu, grożenie przemocą lub jej stosowanie. Jedną z form naruszania nietykalności cielesnej stanowią przestępstwa na tle seksualnym (Bilski, 2006, s. 13; Merecz i in., 2005, s. 10; Szczepanik, 2014, s. 11; Delikowska, 2009, s. 12).

\section{MOBBING W PRAKTYCE POLSKICH PRZEDSIĘBIORSTW}

Wyniki badań przeprowadzonych przez CBOS w latach 2002 i 2014 ilustruje wykres 1, znajdujący się na następnej stronie. W obu badaniach niekorzystne zachowania zgłaszało ok. 14\% pracowników.

Najbardziej rozpowszechnione w miejscu pracy są nadużycia werbalne (11\%). Upokarzania lub groźby dotknęły 5\% pracowników ${ }^{4}$. W Polsce ten problem w pełnym spektrum dotyka nawet co 20-stą osobę zatrudnioną (5\% zatrudnionych deklaruje, że często spotyka się z szykanami ze strony przełożonych oraz koleżanek i kolegów z pracy), a pojedynczych szykan doświadcza kolejne $12 \%$ pracowników ${ }^{5}$. 
Wykres 1.

Wyniki badań przeprowadzonych w 2002 i 2014 r. - „Czy był Pan/ Pani szykanowany/a w ciągu ostatnich pięciu lat?”

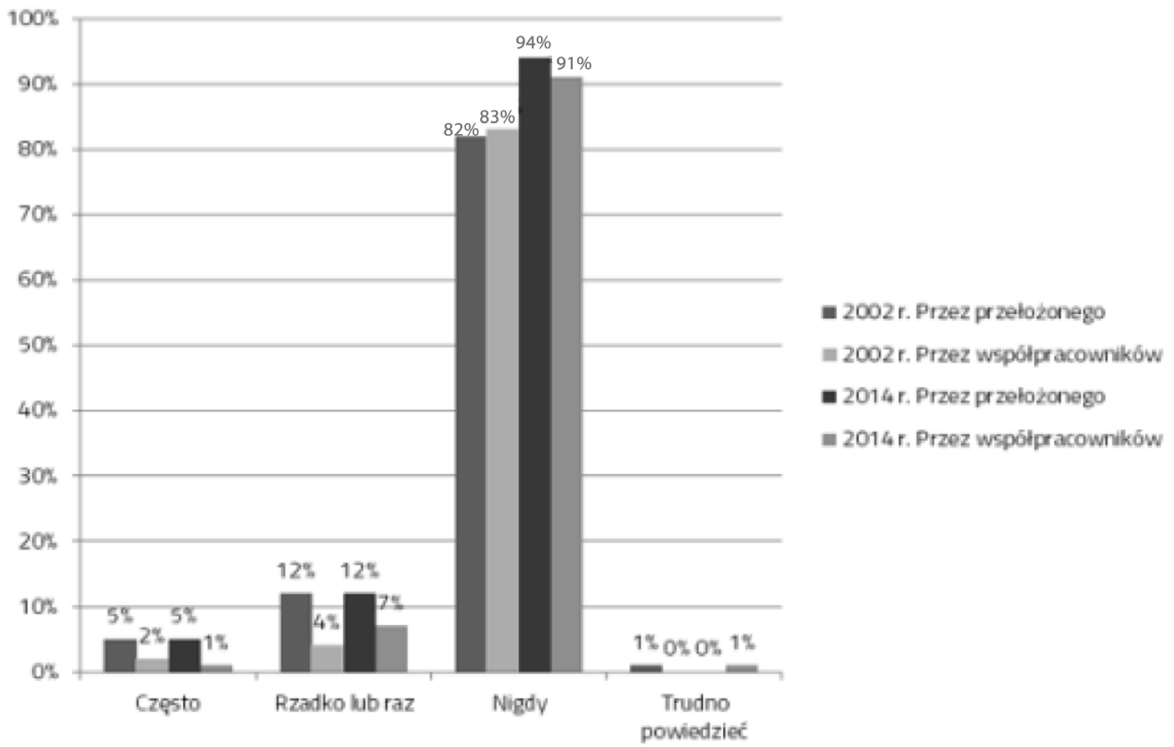

Źródło: badania CBOS-u „Szykany w miejscu pracy”, raporty z badań nr 107/2002 i 109/2014.

Centrum Badania Opinii Społecznej w 2014 r. opublikowało wyniki drugiej edycji badania „Szykany w miejscu pracy” (pierwszą edycją tego samego badania przeprowadzono w 2002 r.). W obu edycjach poproszono Polaków o ocenę sytuacji w ich miejscach pracy w ostatnich 5 latach. Obie edycje badania zostały przeprowadzone tuż po globalnym kryzysie ekonomicznym, jednak różniły się tym, że pierwsza odbyła się, gdy kwestie nękania w miejscu pracy nie były jeszcze uregulowane.

Czy wprowadzone w 2003 r. w Polsce uregulowania zmieniły coś w środowisku pracy i ukształtowały świadomość pracowników? Z porównania wyników obu badań wynika, że poziom występowania zachowań odbieranych przez pracowników jako szykany stosowane przez bezpośredniego przełożonego nie uległ zmianie (różnica odpowiedzi 5\%). Szykany ze strony koleżanek i kolegów z pracy są rzadsze niż ze strony przełożonych, w porównaniu z 2002 r. zmniejszyły się w niewielkim stopniu (różnica wyników 1\%). 
Badanych, którzy zadeklarowali, że byli szykanowani przez swoich przełożonych lub koleżanki i kolegów z pracy, zapytano, jakie zachowania uznawali za szykany. Najczęściej pojawiające się zachowania przedstawia poniższa tabela.

Tabela 1.

Szykany w miejscu pracy. Opracowanie własne na podstawie raportu CBOS- $\mathbf{u}^{6}$. Wartości procentowe nie sumują się do 100 , gdyż badani mogli wymienić kilka różnego rodzaju szykan

\section{Jakie zachowania uznano za szykany?}

Bezzasadna krytyka, upokarzanie, podważanie autorytetu, tworzenie złej atmosfery w miejscu pracy, np. obrażanie się, podnoszenie głosu, poniżające traktowanie, nieuzasadnione pretensje, okazywanie władzy wobec pracowników w niewłaściwy sposób, głośne obgadywanie za plecami, mobbing psychiczny, poniżanie pracowników, traktowanie pracownika jak kogoś, kto zajmuje potrzebny etat, nieprzychylność, podważanie kompetencji, ośmieszanie

Kary niepieniężne, ograniczenia i represje, np. zmuszanie do wykonywania pracy ponad siły, obciążanie nadmierną liczbą obowiązków, poddawanie presji i stresowi, zmuszanie do zostawania po godzinach, takie zarządzanie, iż problemem dla pracownika jest skorzystanie z przerwy w ciągu 8 godzin, zabieranie dni wolnych, mimo że były już wcześniej ustalone, udzielanie urlopów tylko na tydzień, a nie na 2 tygodnie i to wtedy, kiedy kierowniczce się to podoba, a nie w terminie dogodnym dla pracownika, wcześniejsze ściąganie z urlopu do pracy

Bezzasadne pozbawianie premii, nagród, części wypłat, np. niedotrzymywanie obietnic płacowych, niewynagradzanie pracy ponad normę

Dyskryminacja ze względu na płeć, wiek, sytuację osobistą; nierówne traktowanie przez przełożonych, np. dyskryminowanie z uwagi na płeć, sytuację osobistą, młody wiek, np. argumentowanie, że pracownica powinna dłużej pracować, bo nie ma męża i dzieci

Zastraszanie zwolnieniem z pracy, np. kierowanie do pracownika słów: ,jak się pani nie podoba, to panią zwolnię”, „jeżeli weźmie ktoś L4, to będzie zwolniony”; zastraszanie wyrzuceniem z pracy

Inne formy zastraszania, np. grożenie, że za nadgodziny firma nie płaci; zastraszanie, którego efektem są wypowiedzi pracowników: „po prostu nie można swojego zdania powiedzieć”, „nie można się było upomnieć o prawa pracownika”

Zmuszanie do wykonywania nieprzepisowej pracy, np. wydawanie poleceń wykonania czegoś niezgodnie z przepisami

Skłanianie do donosicielstwa, np. kierowanie do najcięższych prac pracowników, którzy nie $\quad$ 2\% donosili

\begin{tabular}{|l|l|}
\hline Inne zachowania odbierane jako krzywdzące & $6 \%$ \\
\hline Odpowiedzi „trudno powiedzieć”, „nie wiem” & $3 \%$ \\
\hline Odmowa odpowiedzi & $7 \%$ \\
\hline
\end{tabular}

Źródło: opracowanie własne na podstawie raportu CBOS-u. 
Pytani o szykany, jakich doświadczali w miejscu pracy, badani najczęściej (43\%) wymieniali bezzasadną krytykę, podważanie autorytetu i kompetencji, upokarzanie, dyskryminację i zastraszanie zwolnieniem z pracy, tworzenie wrogiej atmosfery w pracy.

Pomimo istniejących już uregulowań prawnych w obszarze mobbingu respondenci doświadczali poniżającego ich traktowania przez przełożonych i przedstawicieli pracodawcy - od bezzasadnej krytyki, nieuzasadnionych pretensji, ośmieszania, a nawet znęcania się psychicznego aż po zachowania stanowiące poważne naruszenia przepisów Kodeksu pracy. Poza tym badani wymieniali złośliwości ze strony kolegów i koleżanek, plotki, donosicielstwo.

Procentowy rozkład wyników tego badania wizualizuje poniższy wykres. Wykres 2.

\section{Charakter szykan najczęściej doznawanych przez pracowników w Polsce}

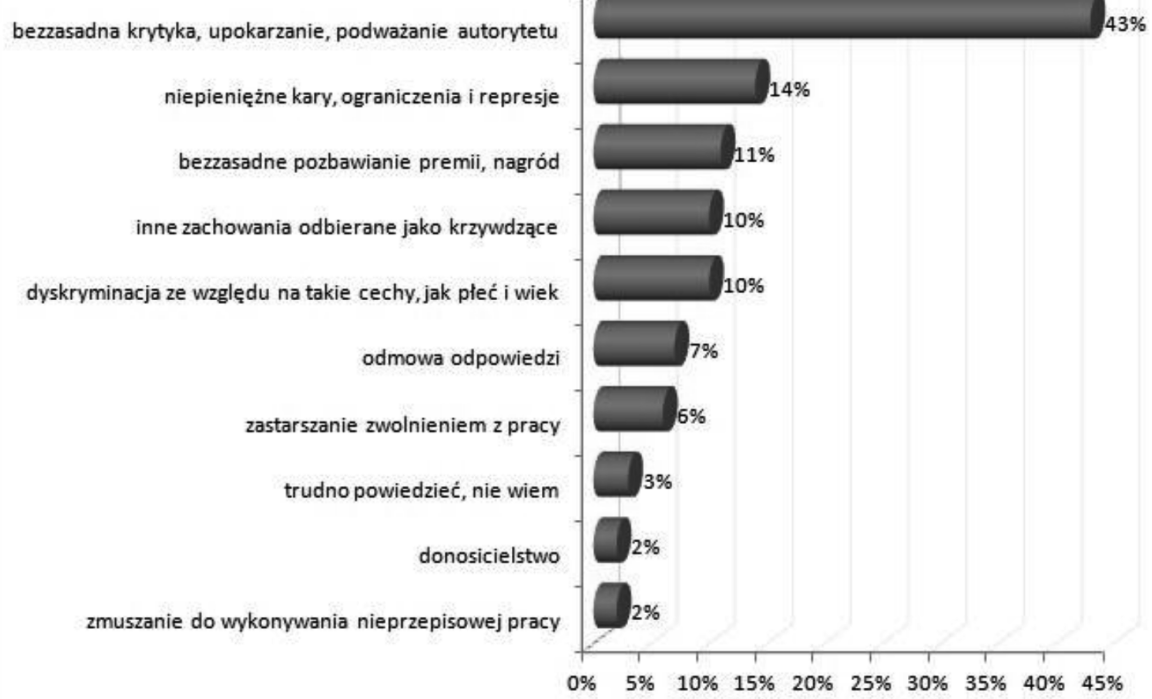

Źródło: opracowanie Sedlak \& Sedlak na podstawie raportu CBOS-u nr 109/2014.

Co istotne, w okresie objętym badaniem zmniejszyła się częstość zastraszania pracowników zwolnieniem z pracy (z 19\% do 6\%) oraz stosowanie niepieniężnych kar i represji (z 20\% do 14\%). Jednak na nieco wyższym 
poziomie (11\%) w porównaniu z danymi roku 2002 (10\%) utrzymuje się bezzasadne pozbawianie pracowników premii czy innych należnych składników wynagrodzenia.

Tabela 2.

Porównanie najczęściej występujących szykan

\begin{tabular}{|c|c|c|}
\hline Szykany & $\mathbf{2 0 0 2}$ & $\mathbf{2 0 1 4}$ \\
\hline Zastraszanie pracowników zwolnieniem z pracy & $19 \%$ & $6 \%$ \\
\hline Stosowanie niepieniężnych kar i represji & $20 \%$ & $14 \%$ \\
\hline $\begin{array}{c}\text { Bezzasadne pozbawianie pracowników premii lub innych składników } \\
\text { wynagrodzenia }\end{array}$ & $10 \%$ & $11 \%$ \\
\hline
\end{tabular}

Źródło: opracowanie własne w oparciu o dane z raportów CBOS-u nr 107/202 i 109/2014.

Badanie szykan w miejscu pracy zrealizowała także firma doradcza Sedlak \& Sedlak w maju i czerwcu 2015 r. Z przeprowadzonej przez nią analizy wynika, że 15\% Polaków doświadcza lub obserwuje zachowania noszące znamiona mobbingu. Niepokojące są informacje wskazujące, że ok. 50\% pracowników nie poinformuje o tym problemie przełożonych lub osób odpowiedzialnych za przeciwdziałanie mobbingowi ze strachu przed szykanami, utratą pracy, itp. Pracowników, którzy w ostatnim półroczu doświadczyli zachowań mobbingowych przynajmniej raz w tygodniu, było 4,88\% (5\% w 2014 r.), a 15,22\% respondentów bywa incydentalnie poddawanych mobbingowi.

Jak pokazują badania, w 2015 tylko 5\% badanych nie doświadczyło w ostatnim półroczu żadnych nieprzyjemnych zdarzeń w miejscu pracy. Z oddziaływaniami obniżającymi poczucie przydatności zawodowej przynajmniej raz w ciągu ostatniego półrocza spotkało się $88 \%$ badanych, $87 \%$ badanych zgłosiło przynajmniej jeden incydent poniżania lub ośmieszania przez współpracowników, $83 \%$ badanych poinformowało o incydentach izolowania i eliminowania z zespołu, 71\% badanych zgłosiło incydenty straszenia i nękania, 75\% badanych twierdzi, że w ich firmach nie podjęto żadnych kroków zapobiegających mobbingowi lub że o nich nie słyszało. Jedynie co czwarty pracownik ma informacje o typu działaniach w zatrudniającej go firmie. 
Respondenci najczęściej wskazywali następujące zachowania mobbingowe, których doświadczali częściej niż raz w tygodniu: 15\% - pomijanie ewidentnych osiągnięć pracownika, 12\% - intencjonalne prowokowanie uczucia strachu i niepokoju oraz 9\% - ignorowanie i lekceważenie wypowiedzi. Natomiast przynajmniej raz w ciągu minionego półrocza: $22 \%$ badanych otrzymało nakaz wykonania czynności naruszającej ich godność, $16 \%$ wysłuchiwało upokarzających przezwisk, 10\% respondentów otrzymywało niestosowne propozycje o charakterze seksualnym (15\% kobiet i $4 \%$ mężczyzn), 9\% badanych było dotykanych wbrew swojej woli (11\% kobiet i $8 \%$ mężczyzn), 6\% badanych straciło swoją własność, bo została zniszczona przez współpracowników lub przełożonych, 3\% badanych usłyszało groźby wobec swoich bliskich, a wobec $2 \%$ badanych używano siły fizycznej.

Poniżej znajduje się graficzne przedstawienie szykan stosowanych względem pracowników w ostatnim półroczu przed badaniem. Pierwszych siedem informacji na wykresie dotyczy zachowań, które jeszcze nie są mobbingiem (występujących ok. raz w miesiącu). Następne trzy zachowania zakwalifikowano jako mobbing $\mathrm{z}$ uwagi na wystąpienie ich co najmniej raz w tygodniu.

Wykres 3.

\section{Szykany stosowane względem pracowników. Opracowanie własne na podstawie raportu Sedlak \& Sedlak 2015}

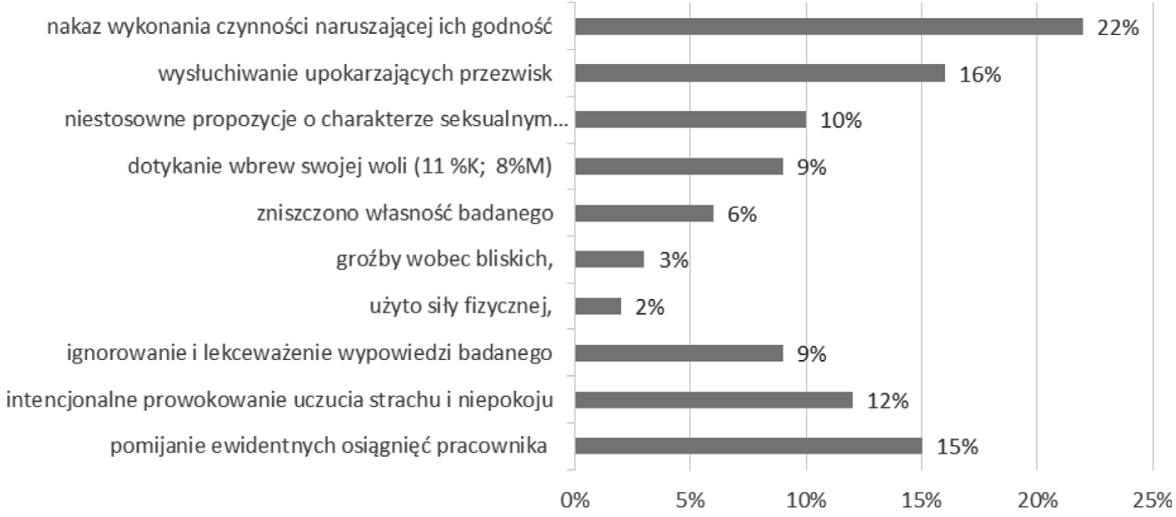

Źródto: Sedlak \& Sedlak, Mobbing w pracy: Alarmujace wyniki badania, 2015. 
Na pytanie, z czyjej strony osoby uważające się za mobbingowane najczęściej doświadczyły prześladowań, wskazania były takie, jak pokazuje poniższy diagram.

Wykres 4.

Z czyjej strony doświadcza Pan/Pani mobbingu

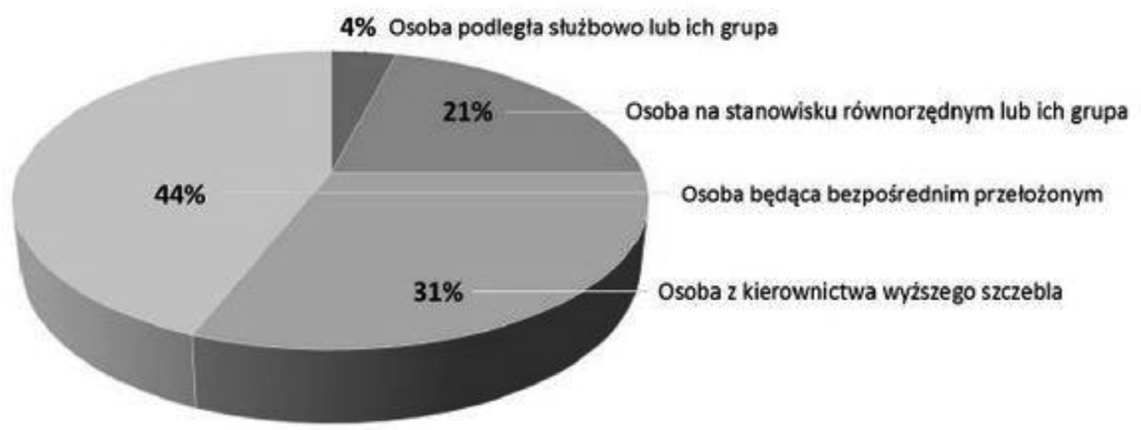

Z czyjej strony doświadcza Pan/Pani mobbingu?

Opracowanie Sedlak \& Sedlak

Źródto: Sedlak \& Sedlak, Mobbing w pracy: Alarmujące wyniki badania, 2015.

Ofiary mobbingu najczęściej doświadczają tego typu nadużyć od bezpośrednich przełożonych (44\%) lub osób z kierownictwa firmy (31\%). Niepokojące są przypadki prześladowań ze strony pracowników na równorzędnych stanowiskach (21\%).

\section{Podsumowanie}

Mobbing pociąga za sobą duże straty dla jednostki, firmy, w sferze społecznej i ekonomicznej. Długotrwałe prześladowania wpływają na przewlekłe pogorszenie samopoczucia u ofiar z powodu strachu przed pójściem do pracy i ciągłego napięcia nerwowego. Psychosomatyczne reakcje organizmu na te emocje mogą doprowadzić do różnych chorób, a w konsekwencji do absencji chorobowej pracownika (Merecz o in., 2005, s. 5-7, 11; Zamorska, 2007, s. 61-62). Ciągłe poczucie zagrożenia w środowisku pracy u niektórych prześladowanych osób budzi zachowania obronne agresywne. Zaburzone relacje między mobbowanym a otoczeniem pogarszają się, co wpływa 
na formowanie opinii o prześladowanej osobie nie tylko w środowisku, ale też na rynku pracy, w konsekwencji utrudniając jej znalezienie nowej pracy (Merecz i in., 2005, s. 12; Wysocki, 2013, s. 197-198; Zamorska, 2007, s. 62). Gnębiona osoba potrzebuje także pomocy psychologa i psychiatry. Co dziesiąty nękany pracownik doświadcza myśli samobójczych, a co setny podejmuje próbę samobójstwa (Merecz i in., s. 11). Z powodu mobbingu straty ponosi także firma. Pogarsza się atmosfera w pracy. Spada motywacja pracowników i wydajność pracy, firma traci często doskonałych pracowników odchodzących z know-how firmy, rosną koszty dodatkowych szkoleń z powodu rotacji personelu, jak również generowane są koszty zwolnień chorobowych, sądowe i związane z wypłatą odszkodowań (Zamorska, 2007, s. 62). Firma traci dobre imię na rynku pracy. Warto też podkreślić, że praktyki mobbingowe generują ogromne koszty w wymiarze ekonomicznym, związane z wydatkami państwa na opiekę medyczną i rentową oraz wcześniejszym przechodzeniem pracowników na emeryturę. Jak widać, mobbing nie tylko wpływa na funkcjonowanie poszczególnych pracowników, rzutuje też na sytuację całego społeczeństwa (Zamorska, 2007). Wiele publikacji i badań dotyczących ochrony pracy oraz mobbingu świadczy o tym, że ten obszar nabiera coraz większego znaczenia dla społeczeństwa. Wśród pracowników rośnie świadomość ich praw, chociaż z badań wynika, że jedna czwarta pracowników nie zna przepisów dotyczących mobbingu, a bardzo podkreśla rolę kierownictwa w dbałości o satysfakcję pracownika $\mathrm{z}$ pracy ${ }^{7}$.

\section{WNIOSKI}

Aanaliza badań wskazuje, iż pomimo istniejących przepisów krajowych i na poziomie UE na przestrzeni 12 lat ciągle ok. 5\% pracowników doświadcza mobbingu, co może świadczyć o tym, że istniejące przepisy nie chronią wystarczająco pracowników. Czy dzieje się tak dlatego, że mobbing jest pojęciem nowym w naszym porządku prawnym i nie jest jeszcze poparty utrwalonym orzecznictwem?

Można by postawić tezę, że pomimo surowego prawa i wzrostu świadomości pracowników poziom szykan nie zmienił się i pozostał na poziomie sprzed uregulowań prawnych. Warto jednak podkreślić, że badani odpowiadali na pytania, opierając się na swoich subiektywnych odczuciach, wy- 
mieniali przykłady negatywnych doświadczeń i praktyk doświadczanych w miejscach pracy, a te zostały przez badaczy zebrane i pogrupowane tematycznie. Poza tym nie wszystkie wymieniane negatywne zachowania odnoszą się do konkretnych zachowań zawartych w definicji Kodeksu pracy (kp) i innych przepisach. Trudno też powiedzieć, czy niewłaściwe zachowania przełożonych, takie jak „bezzasadna krytyka, podważanie autorytetu, upokarzanie” były kierowane do konkretnej osoby, części lub całego zespołu oraz jak długo i z jaką częstotliwością występowały. Przypadki niewłaściwego traktowania zespołu lub jego części mogą nie wyczerpywać prawnych kryteriów mobbingu, a być wynikiem braku kompetencji kierowniczych przełożonego. Brak umiejętności zarządzania zespołem może zostać zakwalifikowany zgodnie z kp jako „naruszenie godności pracownika czy zasad współżycia społecznego w środowisku pracy”, a nie jako mobbing. W 2004 r. do Inspekcji Pracy wpłynęło ok. 400 skarg na mobbing w pracy, w tym 31 skarg inspektorzy uznali za zasadne, a 43 za częściowo zasadne. Ponad połowę z 400 skarg uznali za niezwiązane z mobbingiem. Dane te dowodzić mogą, że zatrudnieni nagminnie mylą mobbing z naruszaniem ich uprawnień, czym jest np. niewypłacanie pensji.

Według ostatnich danych Ministerstwa Sprawiedliwości w latach 2014-2016 liczba skarg osiągnęła poziom ok. 600 rocznie i mogłaby zostać w znacznej mierze zniwelowana dzięki interwencjom zapobiegawczym. Niestety niewiele polskich przedsiębiorstw wdrożyło programy przeciwdziałania mobbingowi i złemu traktowaniu, w związku z czym tylko niewielka grupa pracowników zgłasza skargi i sygnalizuje przypadki niewłaściwego traktowania. Część pracowników, chociaż ma takie możliwości, nie robi tego w obawie przed represjami i utratą pracy. Na drogę sądową występują najczęściej byli pracownicy, którzy z powodu negatywnych praktyk zmuszeni zostali do odejścia z pracy lub zostali zwolnieni przez pracodawcę.

\section{Literatura}

Bechowska-Gebhardt, A., Stalewski, T. (2004). Mobbing: patologia zarzadzanie personelem, Warszawa: DIFIN.

Bilski, Ł. (2006). Psychologiczne uwarunkowania stosunku pracy i ich wpływ na rozwój przedsiębiorstwa, Praszka: Wydawnictwo Naukowe UM im. K. Marcinkowskiego. 
Chakowski, M. (2005). Mobbing. Aspekty prawne, Bydgoszcz-Warszawa: Oficyna Wydawnicza Brante.

Delikowska, K. (2009). Raport z badań na temat działań mobbingowych $w$ miejscu pracy, WRZOS, „Społecznik” Nr 7.

Kędziora, K., Śmieszek, K. (2010). Dyskryminacja i mobbing w zatrudnieniu, Colonel: Warszawa.

Łaszkiewicz, K. (2014). Mobbing - uproszczona analiza zjawiska w środowisku policyjnym za okres czerwiec-grudzień 2013 rok, „Ruch Prawniczy, Ekonomiczny i Socjologiczny" Warszawa.

Merecz, D., Mościcka, A., Drabek, M. (2005). Mobbing w środowisku pracy. Charakterystyka zjawiska, jego konsekwencje, aspekty prawne i sposoby przeciwdziałania, Łódź: Instytut Medycyny Pracy im. J. Nosfera.

Ostrowska, M. (2013). Mobbing w środowisku pracy, Studia i Materiały, „Miscellanea Oeconomicae" R. 17, Nr 1.

Rybak, M. (2008). Zjawisko mobbingu a budowanie zaufania w organizacji, „Annales. Etyka w życiu gospodarczym" R. 11, Nr 1.

Śmierciak, Ł., Mobbing. Jak się bronić? Jak zapobiegać?, PARP - Kapitał ludzki 2013.

Szczepanik, E. (2014). Zjawisko mobbingu w organizacjach, „Dylematy” Nr 3.

Szewczyk, H. (2012). Mobbing w stosunkach pracy. Zagadnienia prawne, Warszawa: Wydawnictwo Naukowe Scholar.

Szkatuła, J. (2010). Zjawisko mobbingu wśród gimnazjalistów, „Studia Gdańskie. Wizje i rzeczywistość" $\mathrm{Nr} 8$.

Wysocki, S. (2013). Przyczyny mobbingu oraz zapobieganie mobbingowi w organizacji - badania w przedsiębiorstwie komunikacyjnym, „Nauki Społeczne = Social Sciences" Nr 2(8).

Zamorska, J. (2007). Mobbing: zamach na godność w pracy, Wrocław: Studio Edytor.

Kępniak, A., Seminarium Okręgowego Inspektoratu Pracy w Łodzi „Stres w pracy”, 15.11.2006, Mobbing w miejscu pracy - uregulowania prawne wynikające z przepisów Kodeksu pracy oraz prawa cywilnego.

CBOS, Komunikat z badań CBOS Nr 109/2014: Szykany w miejscu pracy, Warszawa 2014.

Raport Sedlak \& Sedlak. (2015). Mobbing w pracy: Alarmujące wyniki badania.

Ustawa z dnia 26 czerwca 1974 r. wraz ze zmianami w 2003 r. Kodeks pracy. 


\section{Źródła internetowe}

Europejska Fundacja na Rzecz Poprawy Warunków Życia i Pracy, Raport: luty 2015 https://www.eurofound.europa.eu/pl/publications/executive-summary/2015/ working-conditions/violence-and-harassment-in-european-workplaces-extentimpacts-and-policies-executive-summary (dostęp: 21.12.2017).

Leymann, H., The Mobbing Encyclopedia, 1996, http://www.leymann.se.

Mobbing: pytania $i$ odpowiedzi, www.wojsko-polskie.pl; http://www.wojsko-polskie. pl/f/galleries/files/2016/5/mobbing_pytania_i_odpowiedzi.pdf (dostęp: maj 2016).

Obliczanie kosztów zwiazanych ze stresem $w$ pracy i innymi zagrożeniami psychospołecznymi, https://www.ciop.pl - Centralny Instytut Ochrony Pracy, Państwowy Instytut Badawczy.

\section{Endnotes}

1 Ustawa z dnia 26 czerwca 1974 r. - Kodeks pracy.

2 Op. cit., $\$ 2$.

${ }^{3}$ Orzeczenie Sadu Najwyższego z 29 czerwca 2005 r. (I PK 290/04), zgodnie z którym uporczywe nękanie lub zastraszanie pracownika może trwać jedną dniówkę roboczą, natomiast ważna jest jego uporczywość.

${ }^{4}$ Europejska Fundacja na Rzecz Poprawy Warunków Życia i Pracy, Raport: luty 2015; https://www.eurofound.europa.eu/pl/publications/executive-summary/2015/ working-conditions/violence-and-harassment-in-european-workplaces-extentimpacts-and-policies-executive-summary (dostęp: 24.02.2015).

${ }^{5}$ Raport CBOS, Szykany w miejscu pracy, Warszawa 2014.

${ }^{6}$ Raport CBOS, Szykany w miejscu pracy, nr 109/2014.

7 Raport Sedlak \& Sedlak, 2015.

${ }^{8}$ Komentarz Doroty Strzelec, psychologa pracy, dyrektorki firmy doradczej StaffPoland Sp. z o.o. 